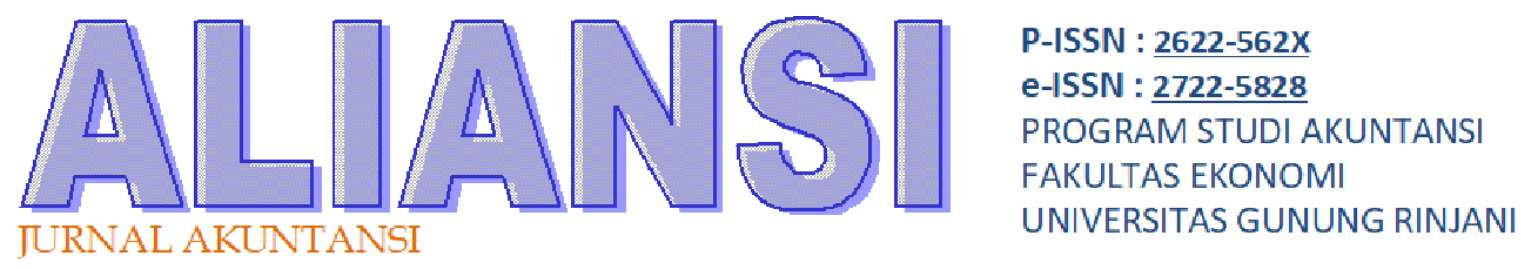

DAN KEUANGAN SYARIAH

\title{
ANALISIS PENGARUH PEMASUKAN DAERAH DAN PENGELUARAN DAERAH TERHADAP PENINGKATAN EKONOMI DI DAERAH TINGKAT II LOMBOK TIMUR TAHUN 2010-2019
}

\author{
SAHRUL IHSAN \\ Universitas Gunung Rinjani \\ E-mail : sahrulihsan751@gmail,com
}

\begin{abstract}
ABSTRAK
Penelitian ini bertujuan untuk mengetahui pengaruh pemasukan daerah dan pengeluaran daerah Terhadap Pertumbuhan Ekonomi di Daerah tingkat II Lombok Timur . Untuk mengetahui besar pengaruhnya antara variabel independen dengan variabel dependen dipergunakan persamaan Regresi Linier Berganda. Sedangkan untuk mengetahui pengaruh positip dan significan atau tidak berpengaruh dan tidak significan digunakan pengolahan data dengan menggunakan SPSS.

Hasil penelitian menunjukkan bahwa, Pemasukan daerah secara parsial tidak berpengaruh terhadap Pertumbuhan Ekonomi. Hasil diperoleh untuk t table sebesar 1.89458. Karena t hitung $<\mathrm{t}$ table $(-0,869<1,89458)$ maka Ho 1 diterima, Ha 1 ditolak. Artinya Pemasukan daerah secara parsial tidak berpengaruh terhadap Pertumbuhan Ekonomi di daerah tingkat II Lombok Timur. Diperoleh tingkat signifikansi sebesar 0,410.Karena tingkat signifikasnsi > 0,05 $(0,410>0,05)$ maka $\mathrm{H}_{01}$ diterima. Artinya Pemasukan daerah secara parsial tidak berpengaruh terhadapPertumbuhanEkonomi.Sedangkan pengeluaran daerah tidak berpengaruh terhadap Pertumbuhan Ekonomi di daerah tingkat II Lombok Timur. Diperoleh tingkat signifikansi sebesar 0,758 Karena tingkat signifikasnsi $>0,05(0,758>0,05)$ maka $\mathrm{H}_{02}$ diterima.Artinya Pengeluaran daerah secara parsial tidak berpengaruh terhadap Pertumbuhan Ekonomi di daerah tingkat II Lombok Timur.
\end{abstract}

Kata Kunci : Pemasukan Daerah, Pengeluaran Daerah dan Peningkatan Ekonomi

\section{PENDAHULUAN}

Pemasukan daerah yang di proleh dari sumber - sumber pemasukan di dalam daerahnya sendiri .Pemasukan daerah itu sendiri di pungut berdasarkan peraturan daerah yang sesuai dengan peraturan perundang -undangan yang berlaku di indosnesia (www.hestanto.web.id.com). 
Adapun factor-faktor yang dapat meningkatkan peningkatan ekonomi yaitu melalui kebijakan pemerintah, mengembangkan teknologi, meningkatkan tabungan, dan meningkatkan efisiensi penambahan modal (investasi) yang dijalankan (Adiatmojo, Gatot Dwi. 2003).

Pemerintah memiliki kewajiban mutlak dalam mengumpulkan sumber-sumber dana(pemasukan) untuk membiayai seluruh pengeluaran yaitu pengeluaran rutin (belanja rutin) dan pengeluaran pembangunan. Agar terwujud sasaran yang tepat dalam pengumpulan dana dan pembiayaan makapemerintah menyusun Anggaran Pemerintah Belanja Negara (APBD)(Sukirno : 2006).

prioritas yang direncanakan. Adapun sumber-sumber pemasukan Pemerintah Daerah,(Munir.2000) terdiri dari:

1. Pemasukan Asli Daerah ( PAD )

2. Dana Perimbangan

3. Pinjaman Daerah

4. Lain - lain pendapatan daerah yang sah

Dari kempat kelompok pemasukan daerah tersebut, pemasukan asli daerah diharapkan dapat menjadi tulang punggung pelaksanaan pembangunn didaerah yang nantinya juga akan berpengaruh pada peningkatan ekpnomi. Sedangkan belanja rutin yang juga merupakan penentu bagaian besar kecilnya jumblah dana untuk pertumbuhan ekonomi. Belanja daerah adalah belanja yang tertuang dalam APBD yang diarahkan untuk mendukungt penyelengaraan pemerintah, pembangunan dan pembinaan kemasyarakatan. (Tjokroamidjojo, 1990 : 82).

Peningkatan ekonomi yang tinggi adalah keinginan masing-masing daerah, peningkatan ekonomi dapat diukur dengan Produk Domestik Regional Bruto (PDRB), dimana PDRB merupakan nilai tambah dari barang dan jasa yang dihasilkan dalam satu periode biasanya satu tahun ( www.bps.go.id.).

potensi daerah karna pemerintah daerah yang lebih mengetahui kebutuhan, kondisi, dan situasi masyarakat setempat. (Suhartini, 2010)

Namun sampai saat ini disebagaian besar daerah otonomi, pemasukan daerah sendiri atau pemasukan rutin daerah yang terdiri dari pemasukan asli daerah (PAD) dan dana bagi hasil (DBH) yang digunakan sebagai sumber untuk perkembangan pertumbuhan ekonomi daerah ternyata masih lebih dominan digunakan untuk belanja rutin, artinya pengeluaran yang dilakukanpemerintah bukan diarahkan untuk investasi bagi pembangunan yang nantinya akan berdampak positif pada laju pertumbuhan ekonomi. Sehingga adanya dana bantuan dari pemerintah pusat yang lebih mendominasi didalam membiayai pembangunan daerah yang diformulasikan dalam Dana Alokasi Umum(DAU) mengindikasikan tingkat kergantungan pemerintah daerah terhadap pemerintah pusat mash besar (Suhartini, 2010).

Seperti wilayah Kabupaten Lombok Timur yang sampai saat ini masih terus memacu dan berupaya menggagalkan pembangunan untuk meningkatkan laju pertumbuhan ekonomi, sehingga dapat meningkatkan kontribusi PAD terhadap total pemasukan daerah, maka pemerintah Kabupaten Lombok Timur untuk mengalokasikan pengeluaran pembangunan yang ada pada masing-masing sector ekonomi sesuai dengan kebutuhan dan segala prioritasnya(Stianingrum, Nugrahani.2005).

Upaya-upaya yang paling dominan yang sedang dilakukan pemerintah daerah Kabupaten Lombok Timur sekarang ini didalam menggali potensi daerah sendiri sebagai sumber penerimaannya adalah dengan mengembangkan sector pariwisata. Selain itu, pemerintah juga ingin memberikan kontribusi yang tinggi dalam sector pertanian agra dapat menjadi salah satu 
penerimaan dn pengeluaran daerah yang efisien dan efektif. Karena dibeberapa Daerah di Kabupaten Lombok Timur memiliki potensi yang besa (Suhartini,2010).

Jadi dengan peningkatan pemasukan asli daerah tersebut diharapkan dapat meningkatkan besaran total pemasukan pemerintah daerah dalam membentuk dana bagi pembangunan daerah tersebut. Karena pemasukan asli daerah mempunyai arti dan peran penting terhadap kemajuan pembangunan daerah yang nantinya dapat meningkatkan laju pertumbuhan ekonomi. Peningkatan total pendapatan daerah ini diperlukan dalam membiayai pembanguna daerah, karena adanya kebutuhan dan keinginan masyarakat yang tak terbatas dan terus berkembang, sedangkan sumber daya yang ada terbatas. Jadi peningkatan pendapatan yang berasal dari daerah sendiri harus terus diupayakan peningkatannya, sehingga mampu untuk meningkatkan pembanguna daerah tanpa banyak bergantung dari dana bantuan pemerintah pusat, dan dengan memperkecil pembiayaan rutin(Suhartini, 2010).

\section{Landasan Teori}

\section{Keuangan Daerah dan Anggaran Daerah}

Kebijaksanaan keuangan pemerintah daerah mempunyai pengaruh yang sangat besar terhadap harga-harga, upah, tabungan, dan pola investasi didaerah yang merupakan hal yang sangat penting bagi pembangunan. Kebijaksanaan anggaran keuangan daerah merupakan realisasi kebijaksanaan fiscal dalam pembangunan, maka kebijaksanaan pengaggaran haruslah ditangani dengan sebaik- baiknya, pengumpulan dan penggunaan danaharus disesuaikan drngan kebutuhan pembangunan di daerah. Pendapatan pemerintah didaerah secara selektif harus selalu meningkat, sedangkan pengeluaran harus dilakukan seefisien mugkin, dan seluruh peruses anggaran harus terkoordinasi dengan rapi, sehingga mmampu untuk mebiayai pembangunan.

Dalam rangka mewujudkan pungsi anggaran keuangan daerah dan peristiwa perinsip-perinsip anggaran daerah yang epektif, transparan dan akuntabel, maka dana yang tersedia harus dimanpaatkan sebagai mungkin untuk dapat menghasilkan peningkatan pelayanan dan kesejahteraan yang maksimal untuk kepentingan masyarakat. Oleh karna itu, untuk dapat mengendalikan tingkat efisiensi anggaran, maka dalam perencanaan perlu ditetapkan secara jelas arah dan tujuan, sasaran, hasil dan manpaat hasil yang akan diperoleh masyarakat dari suatu kegiatan peroyek yang diprogramkan,

(Mabrur:2006)

\section{Kinerja Pengelolaan Keuangan Daerah}

Pengelolaan keuangan daerah merupakan pengelolaan anggaran daerah (APBD).Kuangan dan anggaran daerah (APBD) Merupakan alat fisikal pemerintah daerah yang merupakan bagian integral dari keuangan Negara. Oleh karna itu, pengalokasian sumber keuangan dperuntukkan bagi pemerataan pembangunan yang nantinya akan berdampaak padapeningkatan laju pertumbuhan ekonomi sekaligus menciptakan stabilitas ekonomi daerah.

Pemberian otonomi yang luas dan destralisasi kepada kabupaten dan kota memberikan jalan bagi pemerintah daerah untuk melakukan pembaharuan dalam system pengelolaan keuangan daerah yang berortasi pada kepentingan public (Public oriented), Hal tersebut meliputi tuntutan kepada pemerintah daerah untuk membuat laporan keuangan dan transfransi informasi anggaran kepada publick. (Munir, 2004:17). 


\section{Pemasukan Daerah}

Dalam upaya memperbesar peran pemerintah daerah dalam pembangunan, pemerintah daerah dituntut untuk lebih mandiri dalam membiayai kegiatan operasionah rumah tangganya.Berdasarkan hal tersebut dapat dilihat bahwa pendapatan daerah tidak dapat dipisahkan dengan belanja daerah, karena adanya saling terkait dan merupakan satu alokasi anggaran yang disusun dan dibuat untuk melancarkan roda pemerintahan daerah. (Rozali Abdullah, 2002). Walaupun terdapat peluang untuk meningkatkan pendapatan daerah, kesenjangan antara pengeluaran dan penerimaan daerah sepeprtinya akan tetap besar selama kurun wktu mendatang. Hal ini menjadi perhatian utama untuk menciptakan system yang memadai mengenai penerimaan daerah, yaitu dalam bentuk transfer dana dari pusat ke daerah. Sumber-sumber penerimaan daerah dalam pelaksanaan desentralisasi adalah, (Munir,2000):

Pemasukan daerah adalah suatu pemasukan yang menunjukkan kemampuan suatu daerah untuk menghinpun sumber-sumber dana yang membiayai kegiatan daerah. Jadi pengertian pendapatan asli daerah dapat dikatakan sebagai pendapatan rutin usaha-usaha pemerintah daerah dalam memanpaatkan potensi-potensi sumber-sumber keuangan untuk membiayai tugas-tugas dan tanggung jawab, (Sutrisno : 1984, dalam skripsi Yunarko 2007).

\section{Pengeluaran Pemerintah Daerah}

Bruto ( 2009), “ pengaruh APBD terhadap pertumbuhan ekonomi di kabupaten dairi"mengatakan bahwa pengeluaran pemerintah daerahberperan untuk mempertemukan permintaan masyarakat dengan penyedian sarana dan prasarana yang tidak dapat di penuhi oleh swasta. Di katakan pula bahwa pengeluaran pemerintah yang di nyatakan dalam belenja pembangunan bertujuan untuk meningkatkan Kapasitas produksi dalam proyek-proyek yang memacu pada pertumbuhan ekonomi pemerataan pendapatan, peningkatan kesejahteraan, dan program yang menyentuh lasung kawasan yang terbelakang. Pemerintah daerah dituntut dapat berperan aktif dalam mengelola dan mengembangkan sektor fublik dalam upaya meningkatkan pertumbuhan ekonomi daerah.

Pendekatan pada upaya peningkatan pertumbuhan tidak semata-mata menentukan pertumbuhan sebagai satu-satunya tujuan pembangunan daerah, namun pertumbuhan merupakan salah satu ciri pokok terjadinya proses pembangunan. Terdapat berbagai instrumen yang digunakan pemerintah untuk mempengaruhi perekonomian. Salah satunya diantaranya adalah pembelanjaan atau pengeluaran pemerintah. Apabila pemerintahtelah menetapkan kebijakan untuk membeli barang dan jasa, pengeluaran pemerintah mencerminkan biaya yang harus dikeluarkan oleh pemerintah untuk melaksanakan kebijakan tersebut.

\section{Peningkatan Ekonomi}

Peningkatan ekonomi sebagai kenaikan jangaka panjang dalam kemampuan suatu Negara untuk menyediakan semakin banyak jenis barang - barang ekonomi pada penduduknya. Kemammpuan ini tumbuh sesuai dengan kemajuan tehnologi, dan penyesuaian kelembagaan dan idiologis yang diperlukannya(Muta ali,lutfi.2015).

Untuk mengetahui tingkat peningkatan ekonomi regional harus di bandingkan dengan tingkat peningkatan regional dari tahun ke tahun atau dapat diformulasikan sebagai berikut : 


$$
\mathrm{g}=\frac{P D R B-\text { rill }_{1}-P D R B-\text { rill }_{0}}{\text { PDRB }- \text { rill }_{0}} \times 100 \%
$$

Ket. : $\mathrm{g}=$ Tingkat peningkatan ekonomi

PDRB-riil ${ }_{1}=$ Penerimaan nasional untuk tahun dimana tingkat peningkatan ekonominya dihitung.

PDRB-rill $l_{0}=$ Penerimaan nasional pada tahun sebelumnya

Para ahli ekonomi menyagtakan bahwa istilah pertmbuhan ekonomi berbeda dengan istilah pembangunan ekonomi.Menurut Suryana, (2000:3) menerangkan b ahwa pembanunan ekonomi diartikan sebagai suatu proses yang menyebabkan pendapatan perkapita penduduk suatu masyarakat meningkat dalam jangka panjang.Pembangunan ekonomi pada umumnya diderfinisikan sebagai suatu proses yang menyebabkan kenaikan pendapatan riil perkapita penduduk suatu Negara dalam jangka panjang yang disertai oleh perbaikan system kelembagaan.Salah satu indicator penting untuk mengetahui kondisi suatu daerah dalam periode tertentu adalah data Produk Domestik Regional Bruto (PDRB) baik atas dasar harga berlak maupun atas dasar harga konstan.Produk Domestik Regional Bruto adalah nilai tambah yang mampu diciptakan berbagai akgtivigtas ekonomi dalam suatu wilayah. Istilah Produk Domestik Regional Bruto (PDRB) merupakan gabungan dari empat kata, (Setianingrum, 2005) yaitu :

a. Produk, artinya seluruh nilai produksi baik barang maupun jasa.

b. Domestik, artinya perhitungan nilai produksi yang dihasilkan hanya oleh faktor-faktor produksi tersebut dikuasai oleh penduduk atau bukan.

c. Regional, artinya perhitungan nilai produksi yang dihasilkan hanya oleh penduduk tanpa memperhatikn apakah faktor produksi yang digunakan berada dalam wilayah domestic atau bukan.

d. Bruto, maksudnya adalah perhitungan nilai produksi kotor karena masih mengandung biaya penyusutan.

PDRB adalah nilai barang dan jasa yang diproduksikan oleh suatu daerah dalam periode tertentu yang menjual hasil dari warga Negara asing yang bekerja di negara yang bersangkugtan.Sedangkan menurut Gatot Dwi Adiatmojo (2003) dalam " Pemenbangunan Berkelanjutan Dengan Optimasi Pemampaatan Sumber Daya Alam Dalam Membangun Prekonomian Dengan Basis Pertanian Dikabupaten Musi Banyuasin" menjelaskan pengertian PDRB adalah suatu indikator untuk menunjukkan laju pertumbuhan ekonomi suatu daerah, sehingga dapat dilihat penyebab pertumbuhan ekonomi suatu wilayah tersebut. (dalam skripsi Setianingrum, 2005)

Melihat pada uraian PDRB diatas dapat diambil kesimpulan bahwa selain PDRB dikatakan sebagai alat ukur juga merupakan salah satu analisa statistik yang dapat digunakan untuk memperoleh keterangan tentang laju pertumbuhan ekonomi daerag serta dapat digunakan pula untuk menganalisa perubahan tingkat kemakmuran secara riil atas dasar harga konstan pada suatu daerah. PDRB dalam hal ini juga dapat berarti jumblah nilai tambah yang timbul dari semua unit produksi suatu wilayah dalam jangka waktu tertentu. 


\section{METODE PENELITIAN}

Jenis penelitian yang digunakan adalah penelitian kaosal komperatif yaitu penelitian dengan karekteristik masalah berupa hubungan sebab akibat antara dua variabel atao lebih. Penelitian kosual komperatif merupakan penelitian ex post facta, yaitu tipe penelitian terhadap data yang dikumpulkan setelah terjadinya suatu fakta atau peristiwa (dalam Yulianti, 2011). Penelitian ini merupakan pendekatan kuantitatif merupakan penekanan pada penguji teori melalui pengukuran variabel penelitian dengan angka dan melakukan analisis data dengan prosedur satistik. Teknik pengumpulan data yang digunakan dalam penelitian ini adalah study wawancara, kepustakaan dan dokumentar.

Uji signifikasi parameter individual (uji statistik t) bertujuan untuk mengukur seberapa jauh pengaruh satu variabel independen secara individial dalam menerangkan varsial variabel dependen. Penguji secara parsial ini dilakukan dengan cara membandingkan antara tingkat signifikansi t dari hasil penguji dengan nilai signifikansi yang digunakan dalam penelitian ini adalah sebagai berikut: Jika nilai signifikansi t dari masing-masing variabel yang diperoleh dari penguji lebih kecil dari nilai signifikansi yang dipergunakan yaitu sebesar 0,05 maka secara parsial variabel independen berpengaruh terhadap variabel dependen. Juka nilai signifikansi t dari masing-masing variabel yang diperoleh dari pengujian lebih besar dari nilai isignifikansi yang dipergunakan yaitu sebesar 0,05 maka secara parsial variabel independen tidak berpengaruh terhadap variabel dependen.

Uji signifikansi simultan (uji statistik F) bertujuan untuk mengukur apakah semua variabel independen yang dimasukkan dalam model mempunyai pengaruh secara bersama-sama terhadap variabel dependen. Cara membandingkan antara tingkat signifikansi $\mathrm{F}$ dari hasil pengujian dengan nilai signifikansi yang digunakan dalam penelitian ini adalah sebagai berikut: Jika tingkat signifikansi $\mathrm{F}$ yang di peroleh dari hasil pengolahan nilainya lebih kecil dari nilai signifikansi yang digunakan yaitu sebesar 0,05 maka dapat disimpulkan bahwa semua variabel dependen. Jika tingkat signufukansi $\mathrm{F}$ yang diperoleh dari hasil pengolahan nilai lebih besar dari nilai signifikansi yang digunakan yaitu sebesar 0,05 maka daapat disimpulkan bahwa semua variabel independen secara simultan tidak merpengaruh terhadap variabel dependen.

\section{HASIL PENELITIAN DAN PEMBAHASAN}

Tabel 1 Hasil Uji Regresi Linier Berganda Coefficients $^{\mathrm{a}}$

\begin{tabular}{|c|c|c|c|c|c|c|}
\hline \multirow{2}{*}{\multicolumn{2}{|c|}{ Model }} & \multicolumn{2}{|c|}{ Unstandardized Coefficients } & $\begin{array}{l}\text { Standardized } \\
\text { Coefficients }\end{array}$ & \multirow[b]{2}{*}{$\mathrm{t}$} & \multirow[b]{2}{*}{ Sig. } \\
\hline & & B & Std. Error & Beta & & \\
\hline \multirow[t]{3}{*}{1} & (Constant) & 12,983 & 11,134 & & 1,166 & ,277 \\
\hline & pemasukan & $-8,274$ & 9,518 &,- 298 &,- 869 & 410 \\
\hline & pengeluaran & $-1,452$ & 4,550 &,- 109 &,- 319 & ,758 \\
\hline
\end{tabular}

a. Dependent Variable: Pertumbuha_Eko

Sumber : datas sekunder yang diolah (Out Put SPSS)

Nilai konstanta yang diperoleh adalah 12,983 artinya jika Variabel Pemasukan (X1), dan Variabel pengeluaran (X2) bernilai 0 maka akan terjadi peningkatan Ekonomi (y) sebesar 
12,983. Nilai koefisien regresi Pemasukan (X1) mempunyai koefisien regresi dengan arah negatif sebesar -8,274. Jika diasumsikan variabel independen lain konstan, hal ini berarti setiap kenaikan 1 persenpemasukan (X1) maka akan menurunkanPertumbuhan Ekonomi (y)sebesar 8,274 . Nilai koefisien regresi pengeluaran (X2)mempunyai koefisien regresi dengan arah negatif sebesar -1,452. Jika diasumsikan variabel independen lain konstan, hal ini berarti setiap kenaikan 1 persen Dana Pembiayaan (X2)maka akan menurunkanPertumbuhan Ekonomi (y)sebesar 1,452 .

Uji t atau uji koefisien regresi secara persial digunakan untuk mengetahui pengaruh masing-masing variabel independen PAD dan Dana Pembiayaan terhadap variabel dependenden pertumbuhan ekonomi. Untuk menentukan $t$ tabel, $t$ tabel dicari pada signifikansi 0,05/2=0,025 (uji 2 sisi) dengan derajat kebebasan $\mathrm{df}=\mathrm{n}-\mathrm{k}-1$. Pengambilan keputusan berdasarkan signifikansi diterima atau ditolaknya hipotesis yang dilakukan dengan kriteria sebagai berikut: Jika signifikansi $<0,05$ maka hipotesis $\left(\mathrm{Ho}_{1}, \mathrm{Ho}_{2}\right)$ ditolak, berarti secara parsial PAD dan Dana Pembiayaan berpengaruh terhadap Pertumbuhan Ekonomi Kab. Lotim. Jika signifikansi > 0,05 maka hipotesis $\left(\mathrm{Ho}_{1}, \mathrm{Ho}_{2}\right.$ ) ditrima, berarti secara parsial PAD dan Dana Pembiayaantidak berpengaruh terhadap Pertumbuhan Ekonomi Kab. Lotim.

Tabel 2 Hasil Uji t Coefficients $^{\mathrm{a}}$

\begin{tabular}{|c|c|c|c|c|c|c|}
\hline \multirow{2}{*}{\multicolumn{2}{|c|}{ Model }} & \multicolumn{2}{|c|}{ Unstandardized Coefficients } & $\begin{array}{c}\text { Standardized } \\
\text { Coefficients }\end{array}$ & \multirow[b]{2}{*}{$\mathrm{T}$} & \multirow[b]{2}{*}{ Sig. } \\
\hline & & B & Std. Error & Beta & & \\
\hline \multirow[t]{3}{*}{1} & (Constant) & 12,983 & 11,134 & & 1,166 & ,277 \\
\hline & Pemasukan & $-8,274$ & 9,518 &,- 298 &,- 869 & ,410 \\
\hline & pengeluaran & $-1,452$ & 4,550 &,- 109 &,- 319 & ,758 \\
\hline
\end{tabular}

a. Dependent Variable: Pertumbuha_Eko

Sumber : data yang diolah (Out Put SPSS)

Berdasarkan tabel 2 diperoleh nilai koefisien regresi variabel PAD sebesar $-1,452$.Nilai t hitung sebesar -0,869. T tabel dicari pada signifikansi 0,05/2=0,025 (uji 2 sisi) dengan derajat kebebasan $\mathrm{df}=\mathrm{n}-\mathrm{k}-1$ atau 10-2-1= 7. Hasil diperoleh untuk $\mathrm{t}$ table sebesar 1.89458. Karena $\mathrm{t}$ hitung <t table $(-0,869<1,89458)$ maka $\mathrm{Ho}_{1}$ diterima, $\mathrm{Ha}_{1}$ ditolak. Artinya PAD secara parsial tidak berpengaruh terhadap Pertumbuhan Ekonomi Kabupaten Lombok Timur.

Berdasarkan tabel 2 diperoleh tingkat signifikansi sebesar 0,410. Karena tingkat signifikasnsi $>0,05(0,410>0,05)$ maka $\mathrm{H}_{01}$ diterima.Artinya PAD secara parsial tidak berpengaruh terhadap Pertumbuhan Ekonomi Kabupaten Lombok Timur.

Berdasarkan table 2 diperoleh nilai koefisien regresi variabel pengeluaransebesar 0,486. Nilai t hitung sebesar -0,819. T tabel dicari pada signifikansi $0,05 / 2=0,025$ (uji 2 sisi) dengan derajat kebebasan $\mathrm{df}=\mathrm{n}-\mathrm{k}-1$ atau $10-2-1=7$. Hasil diperoleh untuk $\mathrm{t}$ table sebesar 1,89458. Karena $\mathrm{t}$ hitung $<\mathrm{t}$ table $(--0,819<1,89458)$ maka $\mathrm{Ho}_{2}$ diterima, $\mathrm{Ha}_{2}$ ditolak. Artinya pengeluaran secara parsial tidak berpengaruh terhadap Pertumbuhan Ekonomi Kabupaten Lombok Timur.

Berdasarkan tabel 4.10 diperoleh tingkat signifikansi sebesar 0,758 Karena tingkat signifikasnsi > $0,05(0,758>0,05)$ maka $\mathrm{H}_{02}$ diterima.Artinya Dana Pembiayaan secara parsial tidak berpengaruh terhadap Pertumbuhan Ekonomi Kabupaten Lombok Timur. 
Tabel 3 Hasil Uji Simultan (Uji F)

ANOVA $^{\mathrm{a}}$

\begin{tabular}{|ll|r|r|r|r|r|}
\hline Model & & Sum of Squares & Df & Mean Square & F & Sig. \\
\hline 1 & Regression &, 091 & 2 &, 046 &, 525 &, $611^{\mathrm{b}}$ \\
& Residual &, 696 & 8 &, 087 & & \\
& Total &, 787 & 10 & & & \\
\hline
\end{tabular}

a. Dependent Variable: Pertumbuha_Eko

b. Predictors: (Constant), Dana_Pembiayaan, PAD

Sumber : data yang diolah (Out Put SPSS)

Berdasarkan hasil pengolahan data menunjukan Sig 0,611 maka > 0,05 sehingga Ha ditolak, dengan demikian H0 diterima. Berdasarkan output diatas dapat ditarik kesimpulan, bahwa antara $\mathrm{X}_{1}$ dan $\mathrm{X}_{2}$ secara simultan atau bersama-sama tidak mempunyai pengaruh yang signifikan terhadap Y artinya PAD dan Dana Pembiayaan tidak berpengaruh secara simultan terhadap Pertumbuhan Ekonomi kabupaten lombok timur

\section{Pembahasaan Hasil Penelitian}

Semua total penerimaan yang diperoleh pemerintah kabupaten Lombok Timur dari tahun ke tahun mengalami peningkatan. Kondisi ini sangat mendukung sekali, karena peran dari pendapatan daerah tersebut sangat penting baik itu bagi pembangunan atau pertumbuhan ekonomi didaerah Kabupaten lombok Timur. Dimana peningkatan penerimaan daerah bersumber dari pendapatan ali daerah (PAD)

Dalam penelitianini PAD tidak berpengaruh secara psrsial terhadap Petumubuhan Ekonomi Lombok Timur. Salah satu penyebabnya adalah rata-rata tingkat realisasi anggaran belum mencapai target yang telah dianggarkan, itu tercermin dari tingkat realisasi anggaran jumlahnya lebih kecil dibandingkan dengan tingkat target yang telah dianggarkan.

Dilihat hasil pengolahan data nilai koefisien regresi variabel PAD sebesar $-1,452$. Nilai $t$ hitung sebesar $-0,869$. T tabel dicari pada signifikansi 0,05/2=0,025 (uji 2 sisi) dengan derajat kebebasan $\mathrm{df}=\mathrm{n}-\mathrm{k}-1$ atau 10-2-1= 7. Hasil diperoleh untuk t table sebesar 1.89458. Karena $\mathrm{t}$ hitung $<$ t table $(-0,869<1,89458)$ maka $\mathrm{Ho}_{1}$ diterima, Ha $\mathrm{H}_{1}$ ditolak. Artinya PAD secara parsial tidak berpengaruh terhadap Pertumbuhan Ekonomi Kabupaten Lombok Timur. Diperoleh tingkat signifikansi sebesar 0,410.Karena tingkat signifikasnsi $>0,05(0,410>0,05)$ maka $\mathrm{H}_{01}$ diterima.Artinya PAD secara parsial tidak berpengaruh terhadap Pertumbuhan Ekonomi Kabupaten Lombok Timur.

Dalam penelitian ini Dana Pembiayaan tidak berpengaruh secara psrsial terhadap Petumubuhan Ekonomi Lombok Timur. Salah satu penyebabnya adalah rata-rata tingkat realisasi anggaran belum mencapai target yang telah dianggarkan, itu tercermin dari tingkat realisasi anggaran jumlahnya lebih kecil dibandingkan dengan tingkat target yang telah dianggarkan.

Dari data penelitian diperoleh nilai koefisien regresi variabel Dana Pembiayaansebesar 0,486. Nilai t hitung sebesar -0,819. T tabel dicari pada signifikansi 0,05/2=0,025(uji 2 sisi) dengan derajat kebebasan $\mathrm{df}=\mathrm{n}-\mathrm{k}-1$ atau 10-2-1=7. Hasil diperoleh untuk $\mathrm{t}$ table sebesar 1,89458. Karena $\mathrm{t}$ hitung $<\mathrm{t}$ table $(--0,819<1,89458)$ maka $\mathrm{Ho}_{2}$ diterima, $\mathrm{Ha}_{2}$ ditolak. Artinya Dana Pembiayaan secara parsial tidak berpengaruh terhadap Pertumbuhan Ekonomi Kabupaten Lombok Timur. Diperoleh tingkat signifikansi sebesar 0,758 Karena tingkat signifikasnsi > 0,05 $(0,758>0,05)$ maka $\mathrm{H}_{02}$ diterima. Artinya Dana Pembiayaan secara parsial tidak berpengaruh terhadap Pertumbuhan Ekonomi Kabupaten Lombok Timur. 
Dari data penelitianBerdasarkan hasil pengolahan data menunjukan Sig 0,611 maka > 0,05 sehingga Ha ditolak, dengan demikian H0 diterima. Berdasarkan output diatas dapat ditarik kesimpulan, bahwa antara $\mathrm{X}_{1}$ dan $\mathrm{X}_{2}$ secara simultan atau bersama-sama tidak mempunyai pengaruh yang signifikan terhadap $\mathrm{Y}$ artinya Pemasukan daerah dan pengeluaran tidak berpengaruh secara simultan terhadap Pertumbuhan Ekonomi kabupaten lombok timur. Penyebab utamanya adalah tingkat realisasi anggaran lebih rendah dari pada tingkat anggarannya. Sehingga memungkinkan tidak terdampak kepada petumbuhan ekonomi kabupaten lombok timur.

\section{KESIPULAN}

Dilihat hasil pengolahan data nilai koefisien regresi variabel Pemasukan daerah sebesar 1,452. Nilai t hitung sebesar -0,869. T tabel dicari pada signifikansi 0,05/2=0,025 (uji 2 sisi) dengan derajat kebebasan $\mathrm{df}=\mathrm{n}-\mathrm{k}-1$ atau $10-2-1=7$. Hasil diperoleh untuk $\mathrm{t}$ table sebesar 1.89458. Karena t hitung < t table $(-0,869<1,89458)$ maka $\mathrm{Ho}_{1}$ diterima, $\mathrm{Ha}_{1}$ ditolak. Artinya Pemasukan daerah secara parsial tidak berpengaruh terhadap Peningkatan Ekonomi Kabupaten Lombok Timur. Diperoleh tingkat signifikansi sebesar 0,410.Karena tingkat signifikasnsi > 0,05 $(0,410>0,05)$ maka $\mathrm{H}_{01}$ diterima. Artinya Pemasukan Daerah secara parsial tidak berpengaruh terhadap Peningkatan Ekonomi di daerah tingkat II Lombok Timur.

Dari data penelitian diperoleh nilai koefisien regresi variabel Dana Pembiayaansebesar 0,486. Nilai t hitung sebesar -0,819. T tabel dicari pada signifikansi $0,05 / 2=0,025$ (uji 2 sisi) dengan derajat kebebasan $\mathrm{df}=\mathrm{n}-\mathrm{k}-1$ atau 10-2-1= 7. Hasil diperoleh untuk $\mathrm{t}$ table sebesar 1,89458. Karena t hitung $<\mathrm{t}$ table $(--0,819<1,89458)$ maka $\mathrm{Ho}_{2}$ diterima, $\mathrm{Ha}_{2}$ ditolak. Artinya Dana Pembiayaan secara parsial tidak berpengaruh terhadap Pertumbuhan Ekonomi Kabupaten Lombok Timur. Diperoleh tingkat signifikansi sebesar 0,758 Karena tingkat signifikasnsi > 0,05 $(0,758>0,05)$ maka $\mathrm{H}_{02}$ diterima. Artinya Dana Pembiayaan secara parsial tidak berpengaruh terhadap Pertumbuhan Ekonomi Kabupaten Lombok Timur

Dari data penelitianBerdasarkan hasil pengolahan data menunjukan Sig 0,611 maka > 0,05 sehingga Ha ditolak, dengan demikian H0 diterima. Berdasarkan output diatas dapat ditarik kesimpulan, bahwa antara $\mathrm{X}_{1}$ dan $\mathrm{X}_{2}$ secara simultan atau bersama-sama tidak mempunyai pengaruh yang signifikan terhadap $\mathrm{Y}$ artinya Pemasukan Daerah dan pengeluaran daerah tidak berpengaruh secara simultan terhadap Peningkatan Ekonomi di daerah tingkat II lombok timur.

\section{DAFTAR PUSTAKA}

Adiatmojo, Gatot Dwi. (2003) Pembangunan Berkelanjutan Dengan Optimal Sumber Daya Alam di Kabupaten Musi Bayuasin.Universitas Semarang(UNNES).

Berutu, Reza Monanda Brutu. 2009.Pengaruh APBD Terhadap Pertumbuhan Ekonomi Dikabupaten Dairi. Skripsi Universitas Sumatra Barat, Medan.

Ghozali , Imam. 2012. Aplikasi Analisis Multivariate dengan Program SPSS.Badan Penerbit Universitas Diponegoro. Semarang.

M. Hasan Iqbal. Statistik 1. Edisi 1. Jakarta : Bumi Aksara.

Mabrur, khairul.2006. Analis Pembangunan Daerah Kabupaten Lombok Timur Tahun 1999 2004. Skripsi FE UNRAM, Mataram.

Muta ali,lutfi.( 2015 ). Tehnik Analisis Regional Untuk Perencanaan Wilayah, tata ruang, dan Lingkungan.Yogyakarta : Badan Perbit Fakultas gegrafi ( BPFG ) Universitas Gajah Mada. 
Munir, Badrul. 2000 .Memangkas Inefisiensi Anggaran Daerah : Mataram Samawa

Munir, H. Dasrin,DKK. 2004.Kebijakan dan Manajemen Keuangan Daerah. Yogyakarta : YPAPI.

Prasokoputra, Adinugraha, 2013 . Faktor - Faktor yang Mempengaruhi Audit Delay. Skripsi Universitas Islam Syarif Hidayatullah Jakarta.

Stianingrum, Nugrahani. 2005. Pengaruh Pertumbuhan Ekonomi Daerah Terhadap PAD Beserta Pengeluaran Pembangunan Di Kabupaten Blora Tahun 2000 - 2004. Skripsi Universitas Negeri Semarang ( UNNEZ ).

Suhartini, 2010. Pengaruh Penerimaan Dan Pengeluaran Pemerintah Daerah Terhadap Pertumbuhan Ekonomi Di Kabupaten Lombok Timur. ( STKIP)

Sukirno, Sadono. 2006. Pengantar Teori Makro Ekonomi,Edisi 3.jakarta : Raja Grafindo Persada. 